\title{
Distraksi Menonton Efektif Menurunkan Nyeri Ringan Pasien Congestive Heart Failure (CHF)
}

\author{
Achmad Djamil ${ }^{1}$, Dewi Yuliana ${ }^{2}$, Mia Arini ${ }^{3}$ \\ Universitas Mitra Indonesia, Bandar Lampung, Indonesia \\ Email: babedjamil@gmail.com
}

\begin{abstract}
Distraction Watch Effectively Reduces Patient Minor Pain Congestive Heart Failure (CHF). Congestive heart failure (CHF) is a pathophysiological condition in the form of abnormalities in the function of the heart so that the heart is unable to pump blood to meet the needs of tissue metabolism or its ability is only present when accompanied by an abnormally elevated diastolic volume. Providing complementary nursing care with the watch distraction method can help reduce mild to moderate pain in patients with congestive heart failure. The research objective was to determine the effect of distraction watching on mild pain in patients with CHF. The study used a Quasi-Experimental design with one group pre-test post-test design approach. A total sample of 60 respondents was divided into 2 groups and selected using nonprobability sampling with the consecutive sampling technique. The results showed that distraction watch therapy had a significant effect on mild pain in patients with CHF. Distraction watch therapy significantly influences mild pain in patients with CHF.
\end{abstract}

Keywords: Reduce pain, Watch distraction

\begin{abstract}
Abstrak: Distraksi Menonton Efektif Menurunkan Nyeri Ringan Pasien Congestive Heart Failure (CHF). Gagal jantung kongestif (CHF) adalah keadaan patofisiologis yang berupa kelainan fungsi jantung, sehingga jantung tidak mampu memompa darah untuk memenuhi kebutuhan metabolisme jaringan atau kemampuannya hanya ada kalau disertai peninggian volume diastolik secara abnormal. Pemberian asuhan keperawatan komplementer dengan metode distraksi menonton dapat membantu menurunkan nyeri ringan sampai sedang pada pasien gagal jantung kongestif. Tujuan penelitian yaitu mengetahui pengaruh distraksi menonton terhadap nyeri ringan pasien dengan CHF. Penelitian menggunakan desain Quasi Eksperimental dengan pendekatan one group pre-test post-test design. Total sampel sejumlah 60 responden yang dibagi menjadi 2 kelompok dan dipilih menggunakan nonprobability sampling dengan teknik Concecutive sampling. Hasil penelitian menunjukkan terapi distraksi menonton berpengaruh secara signifikan terhadap nyeri ringan pasien dengan CHF. Terapi distraksi menonton berpengaruh secara signifikan terhadap nyeri ringan pasien dengan $\mathrm{CHF}$.
\end{abstract}

Kata kunci: Menurunkan nyeri, Distraksi menonton

\section{PENDAHULUAN}

Gagal jantung adalah masalah kesehatan yang terus berkembang di dunia dengan jumlah penderita lebih dari 20 juta jiwa. Prevalensi gagal jantung sangat meningkat dengan sejalannya pertambahan usia diatas 65 tahun. Menurut World Health Organization (WHO) pada tahun 2016, menyebutkan bahwa 17,5 juta orang meninggal akibat penyakit kardiovaskuler, yang mewakili $31 \%$ kematian di dunia. Di Amerika Serikat penyakit jantung hampir terjadi 550.000 kasus pertahun, sedangkan di negara-negara berkembang di dapatkan kasus sejumlah 400.000 sampai 700.000 per bulan (WHO, 2016).
Rumah Sakit Umum Daerah dr. Hi. Abdul Moeloek Provinsi Lampung merupakan rumah sakit rujukan utama di Provinsi Lampung. Berdasarkan data registrasi pasien yang berkunjung ke Poli Jantung Rawat Jalan Rumah Sakit Umum Daerah dr. Hi. Abdul Moeloek pada bulan Desember 2017 terdapat sebanyak 446 pasien berobat di Poliklinik, saat dilakukan anamnesa 75\% (335 pasien) yang berobat melalui Poli Jantung menyatakan adanya keluhan nyeri di dada. Sedangkan pasien yang dirawat di Ruang Tulip pada bulan Desember 2017 sebanyak 104 pasien, 76 pasien adalah dengan diagnosa CHF. Dibandingkan dengan Rumah Sakit Umum Daerah Ahmad Yani Metro yang merupakan rumah sakit yang memiliki akreditasi yang setara 
dengan Rumah Sakit Umum Daerah dr. Hi. Abdul Moeloek berdasarkan data registrasi rawat jalan pada bulan Desember 2017 terdapat 90 pasien berobat di Poliklinik dan terdapat 37 pasien rawat inap dengan masalah penyakit jantung sebanyak 20 pasien terdiagnosa CHF. Sementara pasien yang di observasi di ruangan rawat inap, berdasarkan pengamatan yang di lakukan penulis pasien mengeluh nyeri dada, hal ini dapat menyebabkan kecemasan, dapat mengurangi kenyamanan dan mengganggu aktifitas klien, karena pasien merasa bahwa jantung itu organ yang sangat vital dan apabila ada nyeri dada pasti ada gangguan di jantungnya.

Disamping pemberian obat-obatan sebagai tindakan kolaboratif dengan dokter untuk mengurangi nyeri, sebagai perawat harus mampu memberikan tindakan keperawatan yang umum untuk membantu mengurangi nyeri yaitu mengkaji sifat, intensitas, lokasi, durasi, dan faktor pencetus dan penghilang nyeri, mengkaji tanda non verbal dari nyeri; memberikan pilihan tindakan rasa nyaman menciptakan lingkungan yang tenang dan bimbingan spiritual. Berdasarkan pengamatan untuk mengurangi nyeri pasien, perawat menganjurkan melakukan teknik relaksasi dengan latihan nafas dalam dan perawat memberikan contoh yaitu dengan menghirup nafas dalam kemudian menghembuskannya perlahan-lahan.

Teknik relaksasi nafas dalam adalah untuk meningkatkan ventilasi alveoli, memelihara pertukaran gas, mencegah atelektasis paru, meningkatkan efisiensi batuk mengurangi stres baik stres fisik maupun emosional yaitu menurunkan intensitas nyeri dan menurunkan kecemasan. Sedangkan manfaat yang di rasakan oleh klien setelah melakukan teknik nafas dalam adalah dapat menghilangkan nyeri , ketentraman hati dan berkurangnya rasa cemas (Smeltzer dan Bare, 2002 ).

Sedangkan teknik distraksi menonton tidak dilakukan karena pasien apabila merasakan nyeri lebih senang dalam suasana yang tenang, jadi tidak memungkinkan untuk menghidupkan televisi untuk pengalihan dari nyeri pasien. Distraksi menonton adalah mengalihkan perhatian klien ke hal yang lain sehingga dapat menurunkan kewaspadaan terhadap nyeri, bahkan meningkatkan tolerasi terhadap nyeri (Prasetyo, 2010 dalam Utami, 2016). Stimulus yang menyenangkan dari luar juga dapat merangrang sekresi endhorphin, sehingga stimulus nyeri yang dirasakan oleh pasien menjadi berkurang. Peredaan nyeri secara umum berhubungan langsung dengan partisipasi aktif individu, banyaknya modalitas sensori digunakan dan minat individu dalam stimulus, oleh karena itu stimulus otak akan lebih efektif dalam menurunkan nyeri (Tamsuri, 2007). Sedangkan tujuan penggunaan teknik distraksi menonton dalam intervensi keperawatan adalah untuk pengalihan atau menjauhkan perhatian klien terhadap sesuatu yang sedang di hadapi, misalnya rasa nyeri. Sedangkan manfaat penggunaan teknik ini pasien merasa lebih nyaman, santai dan merasa berada pada suatu yang lebih menyenangkan (Widyastuti, 2010).

Berkaitan dengan pemberian teknik relaksasi yang sudah ada Standar Prosedur Operasional (SPO), sedangkan untuk teknik distraksi menonton belum ada SPO yang menjadi standar dalam pelaksanaannya serta belum adanya kesimpulan yang menyatakan bahwa teknik mana yang lebih baik dan lebih memungkinkan untuk dilakukan dalam mengurangi ataupun mengatasi nyeri pada pasien $\mathrm{CHF}$, serta belum terpantaunya pemberian latihan teknik distraksi menonton dan teknik relaksasi.

Berdasarkan penelitian oleh Ganeshabala (2006, dalam Mustawan, 2008) tentang perilaku koping pada penderita atritis reumatoid di Poliklinik Geriatrik dan Poliklinik Penyakit Dalam RSUP Dr. Sardjito Yogyakarta. Hasil penelitian menyebutkan bahwa perilaku koping pada pasien atritis reumatoid yang baik maka akan menurunkan keluhan (nyeri) yang dialaminya. Penelitian oleh Basuki (2007) tentang pengaruh tehnik distraksi menonton dan relaksasi terhadap penurunan tingkat nyeri pada pasien fraktur yang mana nyeri awal pada pasien fraktur sebagian besar dari 18 responden atau $88,3 \%$ keluhan/respon pasien berada dalam tingkat nyeri sedang dan berat. Sedangkan $11,7 \%$ responden dalam rentang nyeri ringan karena klien telah beradaptasi dan telah menemukan cara untuk mengatasi nyeri yang dialami.

\section{METODE}

Penelitian menggunakan desain quasi eksperimental yaitu dengan memberikan perlakuan kepada kelompok kasus berupa terapi komplementer teknik distraksi menonton dan kelompok kontrol diberikan teknik relaksasi nafas dalam. Populasi penelitian yaitu pasien CHF di ruang Tulip Rumah Sakit Umum Daerah dr. Hi. Abdul Moeloek sejumlah 60 responden.

Sampel menggunakan tehnik Concecutuve sampling dimana pengambilan data dilakukan terlebih dahulu pada kelompok kasus sampai dengan besar sampel yang diinginkan tercapai, 
selanjutnya pengumpulan data pada kelompok kontrol. Adapun kriteria insklusi penelitian yaitu pasien CHF dengan nyeri ringan sampai sedang (skala nyeri 1-6). Sedangkan kriteria eksklusi yaitu terpasang oksigen, sesak nafas. Berdasarkan kriteria tersebut, maka sampel dibagi menjadi 2 kelompok intervensi yaitu: Kelompok yang diberikan teknik distraksi menonton dan Kelompok yang diberikan teknik relaksasi nafas dalam.

Penelitian ini telah mendapatkan Persetujuan Etik Penelitian Kesehatan (Ethical Clearance) Nomor: 297/EA/KEPK-TJK/XI/2019 dari Komisi Etik Penelitian Kesehatan Politeknik Kesehatan Tanjung Karang.

\section{HASIL}

\begin{tabular}{|c|c|c|c|c|c|}
\hline $\begin{array}{l}\text { Dist } \\
\text { Sesu } \\
\text { Men }\end{array}$ & $\begin{array}{l}\text { ahs } \\
\text { nton }\end{array}$ & Tind & $\begin{array}{l}\text { Sebe } \\
\text { kan } \\
\text { ien } \mathrm{CF}\end{array}$ & $\mathrm{um}_{\text {Distr }}$ & ksi \\
\hline Variabel & Mean & SD & SE & $\begin{array}{c}p- \\
\text { value }\end{array}$ & $\mathbf{n}$ \\
\hline $\begin{array}{l}\text { Nyeri } \\
\text { sebelum } \\
\text { Distraksi } \\
\text { menonton }\end{array}$ & 5,14 & 0,900 & 0.340 & 0,000 & 30 \\
\hline $\begin{array}{l}\text { Nyeri sesudah } \\
\text { Distraksi } \\
\text { menonton }\end{array}$ & 3,57 & 0,976 & 0,369 & 0,000 & 30 \\
\hline
\end{tabular}

Berdasarkan tabel 1 terlihat bahwa dari 30 responden pada kelompok sebelum tindakan distraksi menonton pada pasien CHF didapatkan rata-rata nilai nyeri 5,14 dengan standar deviasi 0,900 sedangkan sesudah intervensi tindakan distraksi menonton nilai rata-rata nyeri 3,57 dengan standar deviasi 0,976 . Hasil uji statistik di dapatkan nilai 0,000 ( $p$-value $=0.000$, di mana $p$ value $<\propto(0.05)$ maka dapat di simpulkan ada perbedaan rata-rata nilai nyeri sebelum tindakan distraksi menonton dengan sesudah tindakan distraksi menonton pada pasien dengan CHF di Ruang Tulip RSUD dr. H.Abdul Moeloek Provinsi Lampung.

Tabel 2. Distribusi Nyeri Sebelum dan Sesudah Tindakan Relaksasi Nafas Dalam pada Pasien CHF

\begin{tabular}{lccccc}
\hline \multicolumn{1}{c}{ Variabel } & Mean & SD & SE & $\begin{array}{c}\boldsymbol{p} \text { - } \\
\text { value }\end{array}$ & $\mathbf{n}$ \\
\hline $\begin{array}{l}\text { Nyeri } \\
\text { sebelum }\end{array}$ & 5,29 & 0,756 & 0,286 & 0,001 & 30 \\
$\begin{array}{l}\text { Relaksasi } \\
\begin{array}{l}\text { Nyeri } \\
\text { sesudah } \\
\text { Relaksasi }\end{array}\end{array}$ & 3,57 & 0,787 & 0,297 & 0,001 & 30 \\
\hline
\end{tabular}

Berdasarkan tabel 2 terlihat bahwa dari 30 responden pada kelompok sebelum tindakan relaksasi nafas dalam pada pasien CHF didapatkan rata-rata nilai nyeri 5,29 dengan standar deviasi 0,756 sedangkan sesudah intervensi tindakan relaksasi nafas dalam nilai rata-rata nyeri 3,57 dengan standar deviasi 0,787. Hasil uji statistik di dapatkan nilai 0.001 ( $p$ value $=0,000$, dimana $p$-value $<\propto(0.05)$ maka dapat di simpulkan ada perbedaan rata-rata nilai nyeri sebelum tindakan relaksasi dengan sesudah tindakan relaksasi pada pasien dengan CHF di Ruang Tulip RSUD dr. H.Abdul Moeloek Provinsi Lampung.

Tabel 3. Perbedaan Selisih Rerata Nyeri Sebelum dan Sesudah Dilakukan Tindakan Distraksi Menonton dan Relaksasi pada Pasien CHF

\begin{tabular}{lccccc}
\hline Variabel & Mean & SD & SE & $\begin{array}{c}p- \\
\text { value }\end{array}$ & $\mathbf{n}$ \\
\hline $\begin{array}{l}\text { Distraksi } \\
\text { menonton }\end{array}$ & 1,571 & 0,535 & 0,202 & 0,000 & 30 \\
Relaksasi & 1,714 & 0,756 & 0,286 & 0,000 & 30 \\
\hline
\end{tabular}

Rata-rata penurunan nilai nyeri pada kelompok tindakan distraksi menonton adalah 1,571 dengan standar deviasi 0,535 , sedangkan kelompok untuk tindakan relaksasi rata-rata penurunan nilai nyeri adalah 1,714 dengan standar deviasi 0,756. Hasil uji statistik didapat nilai $p$-value $=0,000$ berarti pada $\propto($ alpha $) 5 \%$ terlihat ada perbedaan pengaruh tindakan distraksi menonton dan tindakan relaksasi pada pasien CHF di Ruang Tulip RSUD dr.H.Abdul Moeloek Propinsi Lampung 2018.

\section{PEMBAHASAN}

Hasil penelitian menunjukkan bahwa dari 30 responden pada kelompok sesudah tindakan distraksi menonton pasien CHF didapatkan ratarata nilai nyeri 3,57 dengan standar deviasi 0,976 nilai nyeri minimal 2 dan nilai nyeri maksimal 5 . Sedangkan untuk kelompok relaksasi di peroleh data dari 30 responden pada kelompok sesudah tindakan relaksasi pada pasien CHF didapatkan nilai rata-rata nyeri 3,57 dengan standar deviasi 0,787 nilai nyeri minimal 3 dan nilai nyeri maksimal 5.

Hal ini sesuai dengan teori Smeltzer dan Bare (2002) menyatakan bahwa tujuan dari teknik relaksasi nafas dalam adalah untuk meningkatkan ventilasi alveoli, memelihara pertukaran gas, mencegah atelektasis paru, meningkatkan efisiensi batuk mengurangi stres 
baik stres fisik maupun emosional yaitu menurunkan intensitas nyeri dan menurunkan kecemasan. Sedangkan manfaat yang di rasakan oleh klien setelah melakukan teknik nafas dalam adalah dapat menghilangkan nyeri, ketentraman hati dan berkurangnya rasa cemas.

Potter dan Perry (2005) menyatakan bahwa dengan pemberian teknik relaksasi nafas dalam akan memungkinkan meningkatnya suplai oksigen ke jaringan sehingga akan dapat menurunkan tingkat nyeri yang dialami oleh individu. Relaksasi adalah sebuah keadaan dimana seseorang terbebas dari tekanan dan kecemasan atau kembalinya keseimbangan (equilibrium) setelah terjadinya gangguan. Tujuan dari teknik relaksasi adalah mencapai keadaan relaksasi menyeluruh, mencakup keadaan relaksasi secara fisiologis, secara kognitif, dan secara behavioral. Secara fisiologis, keadaan relaksasi ditandai dengan penurunan kadar epinefrin dan non epinefrin dalam darah, penurunan frekuensi denyut jantung (sampai mencapai 24 kali per menit), penurunan tekanan darah, penurunan frekuensi nafas (sampai 4-6 kali per menit), penurunan ketegangan otot, metabolisme menurun, vasodilatasi dan peningkatan temperatur pada extermitas (Rahmayati, 2010).

Stimulus yang menyenangkan dari luar juga dapat merangrang sekresi endhorphin, sehingga stimulus nyeri yang dirasakan oleh pasien menjadi berkurang. Peredaan nyeri secara umum berhubungan langsung dengan partisipasi aktif individu, banyaknya modalitas sensori di gunakan dan minat individu dalam stimulus, oleh karena itu stimulus otak akan lebih efektif dalam menurunkan nyeri (Tamsuri, 2007). Sedangkan tujuan penggunaan teknik distraksi menonton dalam intervensi keperawatan adalah untuk pengalihan atau menjauhkan perhatian klien terhadap sesuatu yang sedang di hadapi, misalnya rasa nyeri. Sedangkan manfaat penggunaan teknik ini pasien merasa lebih nyaman, santai dan merasa berada pada suatu yang lebih menyenangkan (Widyastuti, 2010).

Distraksi menonton sangat efektif dalam mengalihkan perhatian pasien terhadap rasa cemas, ketakutan, dan depresi yang dialami pasien namun hal tersebut dipengaruhi oleh beberapa faktor. Menurut Asmadi (2008), faktor yang mempengaruhi distraksi menonton yaitu komunikasi antar perawat dan klien, media distraksi yang dipakai, jangka waktu yang digunakan serta tingkat stres, cemas maupun depresi yang dialami pasien. Distraksi adalah mengalihkan perhatian klien ke hal yang lain sehingga dapat menurunkan kewaspadaan terhadap nyeri, bahkan meningkatkan toleransi terhadap nyeri. Teknik distraksi dapat mengatasi nyeri berdasarkan teori aktivasi retikuler, yaitu menghambat stimulus nyeri ketika seseorang menerima masukan sensori yang cukup atau berlebihan, sehingga menyebabkan terhambatnya impuls nyeri ke otak (nyeri berkurangatau tidak dirasakan oleh klien). Stimulus sensori yang menyenangkan akan merangsang sekresi endorfin, sehingga stimulus nyeri yang dirasakan oleh klien menjadi berkurang. Distraksi bekerja memberi pengaruh paling baik untuk jangka waktu yang singkat, untuk mengatasi nyeri intensif hanya berlangsung beberapa menit, misalnya selama pelaksanaan prosedur invasif atau saat menunggu kerja analgesik. Perawat dapat mengkaji aktivitasaktivitas yang dinikmati klien sehingga dapat dimanfaatkan sebagai distraksi. Aktivitas tersebut dapat meliputi kegiatan menyanyi, berdoa, menceritakan foto atau gambar dengan suara keras, mendengarkan musik, dan bermain. Sebagian besar distraksi dapat digunakan di rumah sakit, di rumah, atau pada fasilitas perawatan jangka panjang (Tamsuri, 2007).

Sementara penelitian yang dilakukan Ratih (2010) bahwa masase mengurangi intensitas nyeri persalinan kala I. Karena dengan Relaksasi bisa mengurangi nyeri dan membuat nyaman sesorang. Relaksasi secara umum akan membantu menyeimbangkan energi dan mencegah penyakit. Secara fisiologis relaksasi merangsang dan mengatur tubuh, memperbaiki aliran getah bening, sehingga oksigen, zat makanan dan sisa makanan dibawa secara efektif dari jaringan tubuh.

Hasil penelitian menyatakan bahwa dengan relaksasi nafas dalam dan distraksi menonton dapat menurunkan nyeri pada pasien dengan CHF hal ini dapat dilihat pada hasil diperoleh data rata-rata penurunan nilai nyeri pada kelompok tindakan distraksi menonton adalah 1,571 dengan standar deviasi 0,535 , sedangkan kelompok untuk tindakan relaksasi rata-rata penurunan nilai nyeri adalah 1,714 dengan standar deviasi 0,756 . Hasil uji statistik diperoleh nilai $p$-value $=0.000$ berarti pada $\propto($ alpha $) 5 \%$ terlihat ada perbedaan pengaruh tindakan distraksi menonton dan tindakan relaksasi pada pasien CHF di Ruang Tulip RSUD dr.H.Abdul Moeloek Propinsi Lampung 2018. Artinya ada perbedaan yang signifikan rata-rata nyeri setelah dilakukan intervensi pada kelompok disrtaksi maupun relaksasi. Berdasarkan keterangan di atas, maka dapat di simpulkan bahwa terapi non framakologis yaitu relaksasi nafas dalam dan 
distraksi menonton sama-sama menurunkan nyeri.

Penilaian respon intensitas nyeri sebelum dan sesudah dilakukan relaksasi dan distraksi menonton. Intensitas nyeri adalah gambaran tentang seberapa parah nyeri yang di rasakan oleh individu. Pengukuran intensitas nyeri sangat subjektif dan individual. Selain itu, kemungkinan nyeri dengan intensitas yang sama di rasakan sangat berbeda oleh dua orang yang berbeda. Pengukuran nyeri dengan pendekatan objektif yang paling mungkin adalah menggunakan respon fisiologis tubuh terhadap nyeri itu sendiri. Namun pengukuran dengan teknik ini juga tidak dapat memberikan gambaran pasti tentang nyeri itu sendiri (Tamsuri, 2007).

Penilaian intensitas nyeri dapat dilakukan salah satunya dengan skala numerik (Numerik Rating Scale) dalam hal ini pasien menilai nyeri dengan menggunakan skala 0-6. Dari pengukuran awal nyeri didapatkan data terlihat bahwa nyeri responden sebelum tindakan distraksi menonton adalah rata-rata nyeri 5,14 dengan nilai batas bawah pada nyeri skala empat dan nilai batas atas pada skala enam. Sedangkan pada kelompok relaksasi nyeri responden sebelum tindakan relaksasi rata-rata nyeri 5,29 dengan nilai batas bawah pada nyeri skala empat dan nilai batas atas pada skala enam. Hasil penelitian ini sejalan dengan penelitian Idris (2019) yang menunjukkan pemberian tekhnik distraksi melihat dan memegang nald berpengaruh untuk menurunkan intensitas nyeri injeksi/penusukan anasthesi pada klien sirkumsisi.

Nyeri akut yang tidak reda dapat mempengaruhi sistem pulmonari, Kardiovaskuler,gastrointesestinal, endokrin dan imonologi. Berbagai efek yang ditimbulkan dari nyeri pada pasien dengan CHF seharusnya diketahui oleh perawat, agar perawat mampu membantu menggelola nyeri dengan manajemen nyeri yang adekuat dengan melibatkan pasien dan keluarganya. Manajemen nyeri merupakan salah satu cara yang di gunakan di bidang kesehatan untuk mengatasi nyeri yang di alami pasien. Manajemen nyeri yang tepat haruslah mencakup penanganan keseluruhan, tidak hanya terbatas pada pendekatan farmakologis saja, karena nyeri dipengaruhi oleh emosi dan tanggapan individu terhadap dirinya. Secara garis besar ada dua manajemen untuk mengatasi nyeri yaitu manajemen farmakologis dan manajemen non farmalogis (Smeltzer \& Bare, 2002).

Tehnik farmakologis merupakan tindakan kolaborasi antara perawat dan dokter yang menekankan pada pemberian obat yang efektif untuk menghilangkan nyeri terutama nyeri yang sngat hebat dan berlangsung lama (Smeltzer \& Bare). Pemberian analgetik obat tidur dapat juga di berikan untuk mengurangi nyeri. Namun pemakaian yang berlebihan mempunyaai efek samping kecanduan dan dapat membahayakan pemakainya bila over dosis. Metode pereda nyeri non farmakologis merupakan tindakan perawat untuk mengurangi intensitas nyeri sampai dengan tingkat yang dapat di toleransi oleh pasien (Potter \& Perry, 2005). Sekarang telah banyak dikembangkan intervensi keperawatan yang dilakukan untuk mengurangi intensitas nyeri seperti teknik distraksi menonton dan relaksasi.

Untuk membadingkan rata-rata nyeri kelompok tindakan distraksi menonton dan tindakan relaksasi terhadap nyeri sebelum dan sesudah dikalukan intervensi. Hasil uji Dependent Sample $T$ Test untuk nyeri pada pasien dengan $\mathrm{CHF}$ mengalami penurunan, artinya ada perbedaan yang signifikan rata-rata nyeri sebelum dan sesudah distraksi menonton dan relaksasi nafas dalam, dapat dilihat pada tabel diperoleh data pada kelompok sebelum tindakan distraksi menonton pada pasien $\mathrm{CHF}$ didapatkan rata-rata nilai nyeri 5,14 dengan standar deviasi 0,900 sedangkan sesudah intervensi tindakan distraksi menonton nilai ratarata nyeri 3,57 dengan standar deviasi 0,976 . Hasil uji statistik di dapatkan nilai 0,000 ( $p$ value $=0.000$, dimana $p$-value $<\propto(0,05)$ maka dapat di simpulkan ada perbedaan rata-rata nilai nyeri sebelum tindakan distraksi menonton dengan sesudah tindakan distraksi menonton pada pasien dengan CHF di Ruang Tulip RSUD dr. H.Abdul Moeloek Provinsi Lampung 2018. Dan pada kelompok sebelum tindakan relaksasi pada pasien $\mathrm{CHF}$ didapatkan rata-rata nilai nyeri 5,29 dengan standar deviasi 0,756 sedangkan sesudah intervensi tindakan relaksasi nilai ratarata nyeri 3,57 dengan standar deviasi 0,787. Hasil uji statistik di dapatkan nilai 0.001 ( $p$ value $=0,000$, di mana $p$-value $<\propto(0,05)$ maka dapat disimpulkan ada perbedaan rata-rata nilai nyeri sebelum tindakan relaksasi dengan sesudah tindakan distraksi menonton pada pasien dengan CHF di Ruang Tulip RSUD dr. H. Abdul Moeloek Provinsi Lampung 2018.

Hal ini sesuai dengan penelitian yang dilakukan oleh Sarfika dkk (2017) menunjukkan hasil adanya pengaruh teknik distraksi menonton kartun animasi terhadap skala nyeri anak saat pemasangan infus. Dan penelitian Basuki (2007) tentang pengaruh teknik distraksi dan relaksasi terhadap penurunan tingkat nyeri pada pasien fraktur, sebagian besar responden menyatakan berada pada tingkat nyeri dan berat, $11,7 \%$ responden dalam rentang nyeri ringan karena 
klien telah beradaptasi dan telah menemukan cara untuk mengatasi nyeri yang dialami.

Relaksasi bisa mengurangi nyeri dan membuat nyaman sesorang. Relaksasi secara umum akan membantu menyeimbangkan energi dan mencegah penyakit. Secara fisiologis relaksasi merangsang dan mengatur tubuh, memperbaiki aliran getah bening, sehingga oksigen, zat makanan dan sisa makanan dibawa secara efektif dari jaringan tubuh.

Hasil penelitian menyatakan bahwa dengan relaksasi nafas dalam dan distraksi menonton dapat menurunkan nyeri pada pasien dengan CHF hal ini dapat dilihat pada tabel yang mana di peroleh data Rata-rata penurunan nilai nyeri pada kelompok tindakan distraksi menonton adalah 1,571 dengan standar deviasi 0,35 , sedangkan kelompok untuk tindakan relaksasi rata-rata penurunan nilai nyeri adalah 1,714 dengan standar deviasi 0,756. Hasil uji statistik didapat nilai $p$-value $=0.000$ berarti pada $\propto($ alpha $) 5 \%$ terlihat ada perbedaan pengaruh tindakan distraksi menonton dan tindakan relaksasi pada pasien CHF di Ruang Tulip RSUD dr.H.Abdul Moeloek Propinsi Lampung 2018. Artinya ada perbedann yang signifikan rata-rata nyeri setelah dilakukan intervensi pada kelompok disrtaksi maupun relaksasi. Berdasarkan keterangan di atas, maka dapat di simpulkan bahwa terapi non framakologis yaitu relaksasi nafas dalam dan distraksi menonton sama-sama menurunkan nyeri. Namun teknis distraksi menonton lebih efektif dibanding dengan teknik relaksasi nafas dalam karena penggunaan teknik ini pasien merasa lebih nyaman, santai dan merasa berada pada suatu yang lebih menyenangkan. Selain itu juga distraksi menonton sangat efektif dalam mengalihkan perhatian pasien terhadap rasa cemas, ketakutan, dan depresi yang dialami pasien, sehingga pasien teralihkan dari rasa nyeri.

\section{SIMPULAN}

Hasil penelitian menunjukkan terapi distraksi menonton berpengaruh terhadap nyeri ringan pasien dengan CHF. Namun, perawat masih perlu menerapkan terapi komplementer teknik distraksi menonton dalam SOP penanganan nyeri ringan sampai sedang pada pasien dengan gagal jantung kongestif (CHF), serta menyediakan sarana prasarana yang dibutuhkan untuk pemberian terapi komplementer.

\section{DAFTAR PUSTAKA}

Asmadi. (2008). Teknik Prosedural Keperawatan: Konsep dan Aplikasi Kebutuhan Dasar Klien. Jakarta: Salemba Medika.

Idris, S. (2019). Pengaruh Teknik Distraksi Dengan Melihat dan Memegang Nald Terhadap Intensitas Nyeri pada Pasien yang Dilakukan Penyuntikan Anasthesi Sirkumsisi di Medan. [Tesis]. Medan: Fakultas Keperawatan, Universitas Sumatera Utara.

Mustawan, Z. (2008). Hubungan Penggunaan Mekanisme Koping Dengan Intensitas Nyeri Pada Pasien Post Operasi Fraktur Femur di Unit Orthopedi RSU Islam Kustati Surakarta. [Tesis]. Surakarta: Universitas Muhammadiyah Surakarta.

Ngudi Basuki. (2007). Pengaruh teknik distraksi menonton dan relaksasi terhadap penurunan tingkat nyeri pada pasien fraktur ekstrem. $\mathrm{m}$, http://www.poltekkessoepraoen. ac.id/?prm=artikel\&var=detail \&id $=27$

Rahmayanti, Y. N. (2010). Pengaruh Guided Imagery Terhadap Tingkat Kecemasan Pada Pasien Skizoafektif Di RSJD
Surakarta. [Skripsi].

Surakarta: Universitas Muhammadiyah Surakarta.

Ratih, R. H. (2010). Pengaruh Metode Massage Terhadap Pengurangan Intensitas Nyeri pada Persaliinan Kala I di Klinik Bersalin Fatimah Ali I Marindal Medan Tahun 2010. [Karya Tulis Ilmiah]. Medan: Fakultas Keperawatan, Universsitas Sumatera Utara.

Rumah Sakit Umum Hi. Abdoel Moeloek. (2017). Penyusunan Program Dan Laporan Rumah Sakit Umum dr. Hi. Abdul Moeloek. Bandar Lampung.

Potter, P.A., \& Perry, A.G. (2005). Buku ajar fundamental keperawatan: Konsep, proses, dan praktik (Fundamentals of nursing : Concepts, process, and practice). Alih Bahasa Renata Komalasari. Edisi 4. Volume 2. Jakarta: EGC.

Smeltzer, S. C., \& Bare, B. G. (2002). Buku Ajar Keperawatan Medikal-Bedah. Vol. 3. EGC.

Sarfika, R., Yanti, N., \& Winda, R. (2017). Pengaruh Teknik Distraksi Menonton Kartun Animasi Terhadap Skala Nyeri Anak Usia Prasekolah Saat Pemasangan 
Infus Di Instalasi Rawat Inap Anak RSUP DR. M. Djamil Padang. NERS Jurnal Keperawatan, 11(1), 32-40.

Tamsuri, A. (2007). Konsep dan Penatalaksanaan Nyeri. Jakarta : Penerbit Buku Kedokteran EGC.

Utami, S. (2016). Efektifitas Relaksasi Napas dalam dan Distraksi dengan Latihan 5 Jari Terhadap Nyeri Post Laparatomi. Jurnal Keperawatan Jiwa, 4(1), 61-73.
WHO. (2016). Prevention of Cardiovascular Disease. WHO Epidemologi Sub Region AFRD and AFRE. Genewa.

Widyastuti, S. (2010). Marylin. T., Anggriani, W., Rama. W \& Wike. MS (2010). Keperawatan Keluarga: Teknik Distraksi. Fakultas Ilmu Keperawatan, Universitas Indonesia. 